\title{
Da'wah di Youtube: Upaya Representasi Nilai Islam oleh Para Content-Creator
}

\author{
Yuangga Kurnia Yahya" ${ }^{* 1}$, Syamsul Hadi Untung ${ }^{2}$, Indra Ari Fajari ${ }^{3}$ \\ 1,2, 3 University of Darussalam Gontor \\ *yuangga4@unida.gontor.ac.id
}

\begin{abstract}
Youtube is one of the popular media used for preaching. This study aims to analyze the stretch of da'wah on YouTube as an effort to represent Islam and to develop a positive Islamic representation. They use descriptive qualitative methods using the theory of Nidzam alUkhuwwah Hasan al-Banna and Ting-Toome inter-cultural communication in building a positive model of Islam in the Maya world. The author found that the younger generation carried out da'wah's propagation through Youtube and positively, Islam was represented through this preaching. They also access YouTube more than any other media platform. Therefore, somebody can build positive content and opinions in developing Islamic representation. The two strategies found are content-creating and collaboration. Through this research, Islamic da'wah via Youtube can be encouraged and grown to become a reference media in exploring Islam.
\end{abstract}

Keywords: Islamic Da'wah, Communication, Cyber World, Representation of Islam, YouTube

\section{ABSTRAK}

Youtube menjadi salah satu media populer yang digunakan untuk berdakwah. Penelitian ini bertujuan menganalisis geliat dakwah di YouTube sebagai upaya representasi Islam dan Pembangunan Representasi Islam yang Positif. Menggunakan metode kualitatif deskriptif dengan menggunakan teori Nidzam al-Ukhuwwah Hasan al-Banna dan komunikasi antar-budaya Ting-Toome dalam membangun representasi positif dari Islam di dunia Maya. Penulis menemukan bahwa Geliat dakwah dilakukan oleh generasi muda melalui Youtube dan Secara Positif Islam direpresentasikan melalui dakwah tersebut. Mereka juga mengakses YouTube lebih dari platform media lain. Konten dan opini positif dalam pengembangan representasi Islam dapat terbangun. Dua strategi yang ditemukan adalah content-creating dan collaboration. Melalui penelitian ini, dakwah Islam melalui Youtube dapat didorong dan dikembangkan sehingga menjadi salah satu media rujukan dalam mendalami Islam.

Kata Kunci: Dakwah Islam, Komunikasi, Dunia Maya, Representasi Islam, YouTube 


\section{PENDAHULUAN}

Perkembangan teknologi informasi memiliki dampak yang signifikan dalam representasi berbagai hal, termasuk dalam mendakwahkan nilai-nilai Islam. Aksesnya yang tak terbatas membuatnya dapat menjangkau tempat-tempat yang memiliki medan yang sulit untuk berdakwah. Namun di sisi lain, seringkali kemudahan dalam berdakwah ini menjadi boomerang dalam berdakwah.

Fenomena ini disebut Gary R Bunt sebagai 'Digital Islam' (Bunt, 2003). Awalnya, wadah ini merupakan salah satu cara dalam mempropagandakan ajaran-ajaran golongan minoritas dalam Islam kepada khalayak. Golongan minoritas tersebut antara lain adalah Al-Qaeda, ISIS, dan organisasi lainnya. Hasil gerakan ini cukup signifikan dalam merekrut anggota-anggota militan yang baru dalam jumlah yang besar (Bunt, 2003: 2). Salah satu kisah perekrutan dengan jaringan dunia maya ini dapat terlihat dalam film documenter "Jihad Selfie" (Rofiuddin, 2016).

'Kesuksesan' dalam penyebaran ajaran-ajaran organisasi tersebut juga dapat diakomodasi dalam penyebaran nilai-nilai Islam yang moderat dan positif. Hal ini didukung dengan ciri khas konten di dunia maya, yaitu tanpa batas dan siapapun dapat mengakses. Representasi nilai-nilai Islam yang radikal dan menyebarkan terror melalui organisasi-organisasi tersebut perlu diimbangi (bahkan didominasi) dengan konten-konten yang berisi pesan positif dan menyebarkan perdamaian antar pemeluk agama.

Gaung "Revolusi Industri 4.0" semakin sering terdengar di berbagai forum. Loncatan perkembangan teknologi dan internet ini menjadi sebuah keniscayaan yang akan datang menyambut umat manusia hari-hari ini. Setelah era digital, saat ini dunia mulai bersiap memasuki revolusi industri 4.0 yang mensyaratkan kebutuhan manusia akan internet dan membuatnya hidup di dua dunia, dunia nyata dan dunia maya.

Pada 2018, Asosiasi Penyelenggara Jasa Internet Indonesia (APJII) mengeluarkan data statistic terkait pengguna internet di Indonesia. Hasilnya, pengguna internet di Indonesia meningkat mencapai 143,26 juta jiwa pada 2018 atau setara dengan 54,7\% populasi masyarakat Indonesia keseluruhan (Saefulloh, 2019). Bahkan, pada 2019 diprediksi pengguna internet menembus angka 175 juta atau 65,3\% dari total 268 juta penduduk Indonesia (Herman, 2018).

Adapun berdasarkan usia penggunanya, dari angka tersebut, 49,52\% merupakan generasi muda. Pengguna berusai 13-18 tahun berjumlah 16,68\%, usia 19-34 tahun berjumlah 49,52\%, usia 35-53 tahun berjumlah 29,55\%, dan usia di atas 54 tahun berjumlah 4,24\%. Hal ini menunjukkan bahwa mayoritas pengguna internet adalah remaja (Utomo, 2019).

Dari data tersebut, $79 \%$ di antaranya merupakan pengguna internet aktif yang mengakses internet setiap hari. Rata-rata pemakaian internet di Indonesia 
mencapai 8 jam 36 menit (Saefulloh, 2019) dan 3 jam 23 menit di antaranya digunakan untuk mengakses media sosial (Kompas, 1/3/18). Berdasarkan aplikasi yang paling banyak diunduh, berbagai perusahaan di bawah Mark Zuckerberg mendominasi tiga teratas. Secara berturut-turut adalah Whats App, Facebook, Instagram, dan selanjutnya Line. Berdasarkan riset yang dilakukan oleh We Are Social, YouTube menempati posisi pertama media sosial yang paling banyak diakses dengan presentase $43 \%$. Selanjutnya diikuti oleh Facebook dengan 41\%, Whats App 40\%, dan Instagram 38\% (Kompas, 1/3/18). Setidaknya, 130 juta penduduk Indonesia atau 49\% dari total keseluruhan merupakan pengguna media sosial (Haryanto, 2020).

Berbagai data di atas semakin meneguhkan peran penting internet dalam kehidupan manusia saat ini. Di samping itu, media sosial menjadi salah satu konten dunia maya yang paling banyak diakses dan digemari oleh pengguna internet. Dengannya, kebutuhan seseorang untuk berkomunikasi, mengakses informasi, dan mencari hiburan dapat terpenuhi meski sedang jauh dari keramaian.

Mayoritas remaja pengguna internet tersebut juga menggunakan internet, khususnya sosial media sebagai gaya hidup dan juga literasi digital mereka. Mereka cenderung lebih suka belajar melalui berbagai konten internet dan sosial media secara otodidak dibandingkan belajar secara langsung, baik formal di bangku sekolah maupun informal di berbagai kursus dan pelatihan. Termasuk dalam hal belajar ilmu agama.

Hal ini menjadi tantangan sekaligus peluang bagi gerakan dakwah. Sejumlah pengakses sosial media, yang dalam hal ini adalah YouTube, menggunakannya tidak hanya untuk mencari hiburan, namun juga untuk belajar dan mempelajari informasi baru. Setidaknya 86\% pengguna menyatakan mengakses YouTube untuk belajar informasi baru. Hal ini membuat YouTube sedikit demi sedikit mulai menggantikan posisi televisi di ruang rumah masyarakat Indonesia. Tak heran, bila para millennial lebih akrab dengan konten dan kreator di You'Tube dibandingkan para artis di televisi. Hal ini pula yang membuat mereka banyak menggemari para content-creator di You'Tube.

Akses yang tak terbatas dan pembawaan yang menarik menjadi salah satu alasan mereka memilih YouTube. Ketika mengakses internet, mereka juga tidak dapat dibatasi oleh berbagai regulasi. Karenanya, menjadi tugas para pendidik dan pendakwah untuk mulai memanfaatkan media yang ada dalam rangka menyediakan counter-narrative atas berbagai isu-isu palsu (hoax) dan sarat akan kebencian yang menyangkut SARA serta memberikan pembelajaran yang benar akan agama.

Dalam artikel ini, penulis mencoba melihat potensi penggunaan konten YouTube sebagai media dakwah, khususnya dalam ranah hubungan antar agama. 
Berbagai narasi yang tersebar di YouTube tidak sedikit yang mengarah pada radikalisme bahkan terorisme. Karenanya, berbagai konten seperti Daqu Movie, Film Maker Muslim (FMM Studios), NU Channel, Islam Channel, Lentera Islam, Al-Bahjah TV, dan lain sebagainya mulai bermunculan. Namun, apakah berbagai konten tersebut sesuai dengan yang diharapkan, baik secara isi maupun antusiasme penonton? Lantas perlukah kerjasama dengan pihak-pihak contentcreator kenamaan lainnya sebagai salah satu opsi dalam menyebarkan counternarratives dan pesan-pesan perdamaian?

Artikel ini akan bertujuan melihat efektivitas da'wah melalui You'Tube dengan menggunakan da'wah bil chaal. Dua gerakan di dunia maya yang akan diteliti di dalam artikel ini adalah gerakan menciptakan konten (content-creating) dan kolaborasi dengan content-creator ternama (collaboration) untuk memperluas jaringan dan memperoleh penonton yang lebih banyak. Dengan kedua gerakan tersebut, peneliti akan melihat dampak yang dihasilkan dari jumlah penonton dalam video-video tersebut.

\section{HASIL DAN PEMBAHASAN}

Era globalisasi yang dimulai pada akhir abad ke-19 dan awal abad ke-20 memberikan banyak dampak dalam pengembangan budaya dan cara hidup manusia (Al-Rodhan \& Stoudmann, 2006). Pertukaran budaya, ekonomi, ilmu pengetahuan, ideologi, dan informasi mensyaratkan bahwa hari ini adalah sulit untuk menghindari kontak dengan pihak lain. Bahkan, pertukaran dan interaksi ini menjadi sebuah kebutuhan manusia dan masyarakat untuk tetap eksis dan bertahan hidup (Yahya, 2018b). Tanpanya, manusia hanya akan berada dalam lingkaran primitif dan masyarakat tersebut akan berada dalam kepunahan secara bertahap.

Menurut Ting-Toomey, interaksi yang terjadi semakin cepat dengan bantuan teknologi dan media. Setiap harinya, manusia akan dihadapkan pada situasi harus bertemu dengan mereka yang berbeda dengan berbagai latar belakang yang berbeda pula (Ting-Toomey, 1999). Berbagai interaksi tersebut tidak dapat dihindari. Sebaliknya, interaksi ini seharusnya menjadi jalan lebih terbukanya manusia dengan dunia luar. Karenanya, komunikasi antarpersonal, antar komunitas, dan antar budaya yang baik diperlukan dalam meminimalisir berbagai gesekan yang terjadi antara kami (us) dan mereka (the others) (Huntington, 1993; Kim, 1988).

Menurutnya, proses komunikasi antarbudaya harus dimulai dengan pengenalan. Pengenalan tersebut merupakan sikap aktif dari kedua belah pihak terhadap identitas masing-masing. Proses ini diikuti dengan perjumpaan nilai dan orientasi masing-masing pihak baik melalui komunikasi verbal maupun nonverbal (Ting-Toomey, 1999; Yahya, 2018a). Hal inilah yang disebut Hasan al- 
Banna sebagai proses at-Ta'aruf'saling mengenal' (Yahya, 2018a).

Dalam tahap tersebut, akan terjadi banyak kontak antar dua budaya yang berbeda dan menimbulkan berbagai manajemen konflik bersama. Berbagai common words dapat diraih dari pemahaman masing-masing kelompok akan identitas dirinya dan identitas kelompok lain (at-tafahum) (Yahya, 2018a). Puncaknya, akan tercipta kemampuan adaptasi antarbudaya, bahkan transformasi identitas dan kompetensi antar komunitas tersebut (at-ta'awun) (Ting-Toomey, 1999; Yahya, 2018a).

Kemahiran dalam menyikapi kontak budaya tersebut juga memiliki peran penting dalam dakwah Islamiyyah. Dakwah adalah sebuah kegiatan menyeru kepada jalan Allah, yaitu Islam (Zaidan, 2002). Dakwah tidak terbatas hanya berupa kegiatan aktif berupa menyeru dan mengajak, namun juga kepada kegiatan pasif seperti representasi wajah Islam dan nilai-nilai kebaikan di dalamnya. Menurut Zaidan (Zaidan, 2002), konten dakwah bervariasi. Dimulai dari pengertian Islam, rukunnya, keistimewaannya, hukum-hukum yang terdapat di dalamnya, dan berbagai tujuan dari berbagai syariah di dalam Islam.

Materi dakwah tersebut seringkali dimaknai untuk disampaikan dalam bentuk lisan saja. Padahal, dakwah memiliki ruang lingkup yang lebih luas. Syariah Islam yang holistik dan menyeluruh (syumuly) tidak dapat dipahami hanya dengan perantara lisan dan memberikan contoh-contoh saja. Ia perlu sebuah tindakan lebih kongrit dari sekedar ucapan dengan lisan.

Setidaknya ada 3 cara dalam menyampaikan dakwah. Pertama, adalah penyampaian dengan lisan yang merupakan mayoritas cara dalam berdakwah. Kedua, adalah penyampaian dengan tindakan dan perbuatan. Ketiga, adalah penyampaian dengan tingkah laku (siirah) dari da'I itu sendiri (Zaidan, 2002). Bentuk kedua dan ketiga adalah representasi dari nilai-nilai Islam yang tercermin dalam diri da'i dan memiliki pengaruh yang cukup signifikan.

Dakwah dengan tingkah laku dan akhlaq da'i, menurut Zaidan, menjadi salah satu faktor terpenting dalam suksesnya dakwah. Dengan akhlaq dan tingkah laku yang mulia, orang-orang di sekitarnya akan tertarik dengan pribadi da'i yang tidak lain merupakan perwujudan Islam dalam kehidupan sehari-hari (Zaidan, 2002). Dakwah dengan cara ini perlu memperhatikan dua aspek utama, yaitu tingkah laku yang baik (chusnu-l khuluqi) dan kesesuaian perbuatan dengan perkataan (Zaidan, 2002). Tanpa keduanya, dakwah dengan sïrab chasanah tidak dapat membuahkan hasil, bahkan justru dapat memberikan representasi buruk dari agama Islam itu sendiri.

Poin penting lainnya dalam berdakwah adalah penggunaan media. Di era digital ini, dakwah sudah seharusnya juga menggunakan media digital dan internet. Hal tersebut menjadi tuntutan dikarenakan lebih dari setengah populasi Bumi akrab dengan kehidupan di dunia maya. Bahkan, seperti disebutkan di atas, 
mereka berselancar di dunia tidak hanya untuk mencari hiburan, melainkan juga untuk belajar dan mencari informasi.

Penelitian Omar, dkk (Omar, Hassan, \& Sallehuddin, 2015) menyebutkan bahwa media sosial memegang peranan penting dalam penyebaran dakwah. Hal tersebut diperkuat dengan penelitian Hidayatullah (Hidayatullah, 2016) yang menggunakan media Twitter sebagai media dakwah yang efektif. Bahkan, di dalam Twitter terdapar gerakan kultwit (kuliah agama Islam dengan twitter) yang menjadi salah satu alternatif bagi masyarakat dalam mendapatkan informasi tentang agama serta membantu memahami Islam lebih mendalam.

YouTube juga menjadi sarana komunikasi dakwah di Kota Makassar, sebagaimana penelitian yang dilakukan oleh Hajar (Hajar, 2018). Para dai di Makassar banyak memanfaatkan media ini dalam membantu aktivitas dakwah mereka. Mereka juga mengakui bahwa platform ini memiliki banyak kelebihan dibandingkan platform sosial media lainnya sehingga lebih mudah menjangkau para jama'ah.

Para anak-anak dan remaja yang merupakan generasi millennial memiliki kecenderungan tersendiri dalam belajar agama. Mereka lebih suka melihat berbagai pengajian di kanal YouTube dibandingkan harus menghadiri majlis pengajian. Selain tidak perlu pergi jauh, video di YouTube juga lebih efisien dan dapat diputar di mana saja dan berulang-ulang. Sayangnya, tidak sedikit materi dakwah di You'Tube justru berisi ajaran-ajaran yang radikal dan erat dengan terorisme, sehingga justru merusak citra Islam sendiri dan menjerumuskan para generasi muda ke arah ajaran Islam yang menyimpang.

Oleh karenanya, dalam tulisan ini, penulis mencoba melihat peran para content-creator dalam mendakwahkan Islam. Dakwah yang mereka lakukan dapat berupa dakwah dengan lisan, perbuatan, maupun dengan siirah chasanah. Tujuannya adalah untuk melihat seberapa banyak penonton YouTube menyukai tayangan dakwah dan dakwah model apa yang cocok dengan generasi millennial di era digital ini.

Penelitian ini merupakan penelitian kualitatif. Data diambil dari video da'wah yang dirilis di YouTube pada tahun 2019. Obyek penelitian adalah konten YouTube dengan tagar \#creatorforchange, channel Deddy Corbuzier, dan channel Najwa Shihab. Melalui penelitian ini, diharapkan dapat menjadi acuan dalam berdakwah di sosial media yang dapat menarik banyak penonton dan pesan di dalamnya dapat tersebar secara luas.

\section{Geliat Dakwah melalui You'Tube}

Hasil penelitian menunjukkan terdapat dua bentuk upaya dalam da'wah di YouTube. Upaya pertama adalah gerakan content-creating, salah satunya adalah gerakan tanda pagar (tagar) CreatorforChange yang diluncurkan oleh YouTube 
sejak 2017. Gerakan ini merupakan gerakan global di seluruh dunia untuk menyuarakan perubahan-perubahan sosial. Menurut Shinto Nugroho, Heads of Public Policy and Government Relations Google Indonesia seperti dikutip oleh Tekno.kompas (10/03/2017) sekitar 70\% anak muda dan remaja milennial percaya bahwa YouTube memiliki peran dalam membentuk budaya. Adapun lebih dari 50\% mengakui bahwa perspektif mereka berubah setelah menonton YouTube.

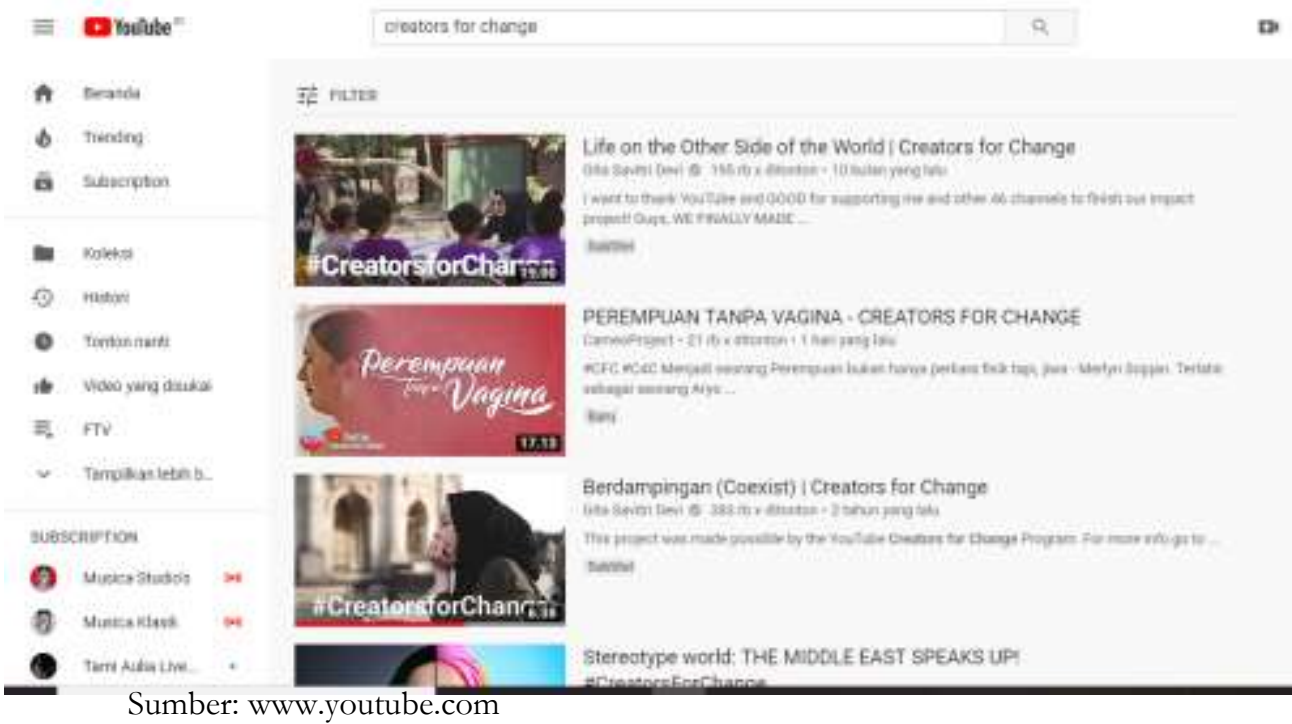

\section{Gambar 1. Hashtag \#CreatorsforChange}

Hal tersebut yang mengilhami pihak YouTube untuk membuat efek positif dengan membentuk gerakan ini. Di Indonesia, gerakan ini bekerjasama dengan dua organisasi non pemerintah (NGO), Ma'arif Institue dan Habibie Center. Adapun content-creator Cameo Project menjadi duta atau perwakilan para kreator.

Gerakan ini mendapat respon positi dari para content-creator. Banyak content-creator kenamaan di Indonesia yang turut serta dalam gerakan ini. Selain channel Cameo Project, ada pula channel Film Maker Muslim, Gita Savitri Devi, Duo Harbatah, dan Kitabisa.com. Hingga 2019, sedikitnya ada 98 video dan terus bertambah yang menggunakan hashtag ini. 


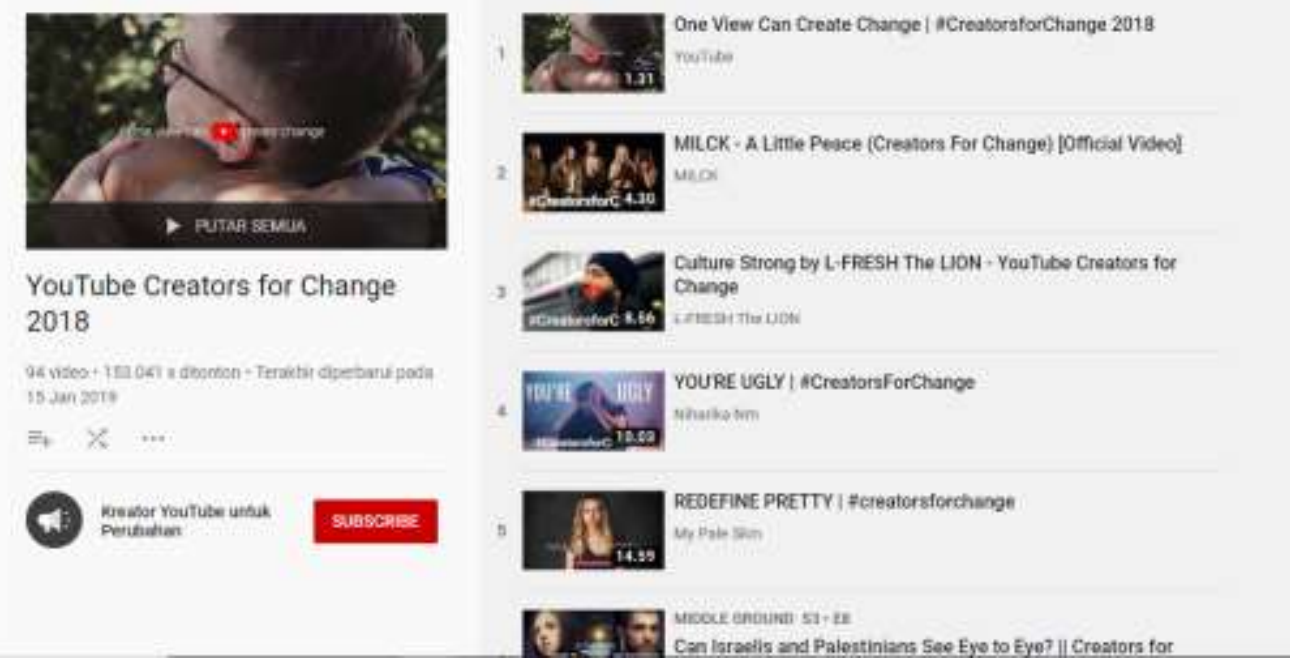

Sumber: www.youtube.com

Gambar 2. Playlisy Creator fo Change 2018

Tema yang diangkat pun beragam. Berbagai isu sosial mulai dari toleransi, strereotyping, body shaming, dan keberagaman menjadi isu sentral yang sering digulirkan. Hal ini merupakan salah satu usaha menyebarkan pesan-pesan positif melalui audio dan video.

Dari segi viewers, gerakan ini memiliki jangkauan yang luas. Bila hanya melihat dari subscribers Cameo Project, mereka hanya memiliki 804 ribu subscribers. Namun, dengan bergabungnya para influencer muda dengan subscribers yang juga banyak, animo penonton akan semakin besar. Katakanlah seperti channel Gita Savitri Devi. Mahasiswi Indonesia yang sedang studi di Jerman ini juga memiliki banyak penggemar. Di channel YouTubenya, ia memiliki 721 ribu subscribers.

Channel Film Maker Muslim juga memiliki jumlah subscribers yang lumayan banyak, yaitu sekitar 555 ribu subscribers. Adapun Duo Harbatah, yang merupakan channel yang cukup terkenal dengan sketsa-sketsa komedia memiliki subscribers sebanyak 1,62 juta subscribers. Semua kalkulasi dari subscribers ini memiliki kemungkinan pangsa penonton yang lebih luas.

Angka-angka tersebut merupakan sebuah hasil yang positif. Hal ini dikarenakan telah banyak konten-konten bermuatan pesan positif, dikarenakan memiliki kemasan yang dianggap kurang menarik oleh para remaja dan strategi promosi yang kurang gencar tidak mendapatkan sambutan menarik dari para netizen. Misalnya adalah channel CISForm (Center for the Study of Islam and Social Transformation). Channel yang dikelola oleh UIN Sunan Kalijaga Yogyakarta ini meluncurkan berbagai animasi yang berisi pesan-pesan narasi tandingan terhadap 
narasi-narasi radikalisme dan fundamentalisme. Namun, berbagai video yang diluncurkan pada Februari 2018 ini hanya memiliki 845 subscribers dan masingmasing video hanya ditonton sekitar 1000-2000 viewers.

Berbagai video yang telah diunggah juga memiliki titik berat pesan yang beragam. Dalam video yang berjudul "Co-existence" yang diunggah Gita Savitri Devi misalnya, menceritakan tentang pengalaman toleransi saat Islam menjadi minoritas di Jerman. Pesan-pesan dalam video tesebut adalah untuk menumbuhkan rasa toleransi yang benar, baik saat menjadi minoritas maupun saat menjadi mayoritas. Hal ini menjadi penting untuk para remaja milennial di Indonesia. Yahya (2018a: 166) juga menyebutkan bahwa pola pikir mayoritas muslim di Indonesia adalah "Ketika Muslim menjadi mayoritas, maka agama lain akan tenteram, sebaliknya, ketika muslim menjadi minoritas, mereka selalu tertindas". Video ini telah ditonton sedikitnya 383 ribu viewers.

Salah satu yang menarik adalah video yang diunggah oleh Channel Komedi Duo Harbatah. Dalam video yang berjudul "Islam itu Damai", mereka mencoba menggulirkan pertanyaan dan statement yang berisi asumsi dan tuduhan bahwa Islam adalah agama yang lekat dengan terorisme. Video ini hadir sebagai respon atas pengeboman gereja di Surabaya oleh kelompok Radikalis yang mengatasnamakan Islam. Berbagai narasi tandingan dari berbagai statement miring tersebut dibahas dalam video yang berdurasi 4 menit tersebut.

Upaya kedua adalah kolaborasi dengan para content-creator kenamaan dengan para tokoh agama yang moderat. Mengapa kolaborasi? Hal ini dikarenakan terbatasnya pengetahuan para remaja milennial akan tokoh-tokoh agama yang memiliki pola pikir moderat dan menyeru kepada kebaikan. Karena saat ini justru cukup banyak pemuka agama yang populer di kalangan remaja adalah mereka yang menyeru pada paradigma jihadis, negara khilafah, dan berbagai isu yang lekat dengan konservatisme. Dengan adanya kolaborasi dengan para YouTubers kenamaan, maka secara tidak langsung memberikan salah satu opsi pemuka agama yang dapat menyikapi berbagai isu keberagaman dan multikulturalisme dengan bijak. Keuntungan lainnya adalah peningkatan jumlah penonton video tersebut dibandingkan bila para pemuka agama tersebut membuat channel sendiri.

Sebagai contoh adalah Ustadz Miftah Maulana Habiburrahman atau yang lebih dikenal dengan nama Gus Miftah. Beliau tidak memiliki channel YouTube khusus dengan nama beliau. Video yang mudah ditemukan adalah video ceramah beliau yang direkam dalam forum pengajian dan sebagainya. Dari segi kualitas visual, video-video tersebut masih "amatiran" dan tidak menarik untuk disaksikan. Hal lainnya adalah penggunaan bahasa Jawa dalam mayoritas forum ceramahnya. Hal ini membuat para penonton videonya hanya berkisar di angka 200-400 ribu viewers. 
Keadan berbeda setelah Gus Miftah berkolaborasi dengan Deddy Corbuzier yang memiliki 5,84 juta subscribers. Beberapa video yang berisi isu-isu berat yang dikemas secara ringan dengan jokes-jokes yang sesuai dengan umur para remaja milennial. Bahasa yang digunakan adalah bahasa Indonesia dengan diksi yang mudah dipahami oleh para penonton. Dalam salah satu video yang berjudul "Makan di rumah orang kafir itu?!" misalnya, mereka berdua mengangkat isu bagaimana cara menghormati pemeluk agama lain yang sedang berpuasa atau sedang menjamu tamunya. Hal sederhana namun pesan yang disampaikan mengena pada permasalahan bagaimana seharusnya hubungan antar muslim dan non-muslim dalam urusan menjamu tamu.

Video tersebut telah disaksikan sebanyak 3,3 juta kali di YouTube. Jumlah yang cukup signifikan dibandingkan video yang berisi ceramah Gus Miftah saja. Bahkan, salah satu video yang mendapat penonton terbanyak adalah video tentang perjalanan Deddy menjadi mualaf dan bagaimana cara Gus Miftah berdakwah di tempat hiburan malam di Yogyakarta. Kedua video tersebut telah disaksikan sebanyak 7,2 juta kali dan 6,5 juta kali. Semua video yang diunggah juga memiliki sisi visual dan thumbnail yang menarik para penonton YouTube.

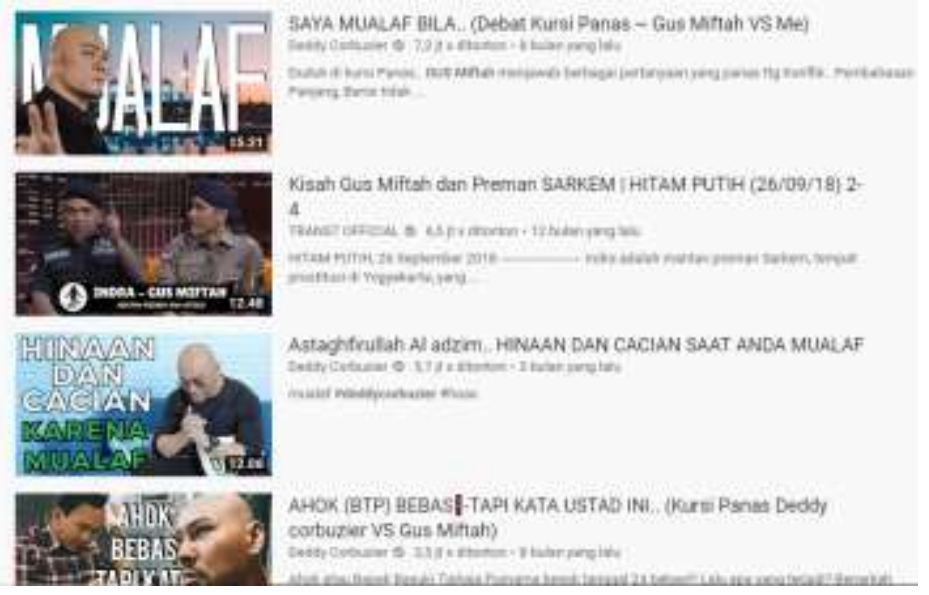

Sumber: www.youtube.com

Gambar 3 Channel YouTube Deddy Corbuzier

Di lain kesempatan, Deddy Corbuzier juga mengajak pemuka agama lainnya untuk berkolaborasi, yaitu Ust. Wijayanto. Ustadz asal Yogyakarta ini juga tidak memiliki channel YouTube sendiri. Berbagai video beliau yang diunggah di YouTube adalah video beliau saat berceramah di berbagai masjid dan forum seperti di masjid Agung Trans Studio Bandung, Masjid Kampus UGM, dan EVIO Multimedia. Sisi visual yang ditampilkan juga tidak begitu menarik. tak heran bila video-video tersebut paling tinggi hanya dilihat sebanyak 
400 ribu kali.

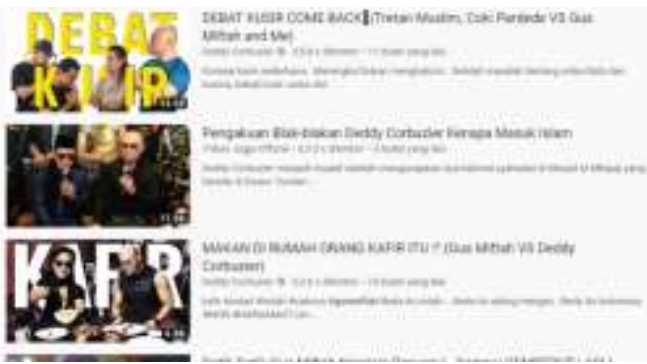

Sumber: www.youtube.com

Gambar 4 Video You'Tube Deddy dan Gus Miftah

Saat Deddy membuat video dengan Ust. Wijayanto, baik di channel YouTube maupun di tayangan Televisi yang ia pandu, Hitam Putih, jumlah viewers meningkat cukup pesat. Dalam video yang berjudul "Pembawa Acara Hitam Putih Kafir, Jangan Ditonton!” misalnya, telah disaksikan sebanyak 3,6 juta hanya dalam waktu 6 bulan. Video yang berisi judul yang cukup provokatif ini sejatinya merupakan jawaban logis dari pengharaman atau penghalalan saat bermuamalah dan mu'asyarah antara Muslim dan pemeluk agama lain. Stereotyping yang sering disebarkan adalah terbatasnya interaksi antar manusia dikarenakan perbedaan keyakinan dan latar belakang agama masing-masing. Dalam video ini, Ust. Wijayanto dengan ringan dan santai serta diselingi jokesjokes mencoba mendudukkan berbagai statement miring tersebut dengan narasinarasi yang positif.
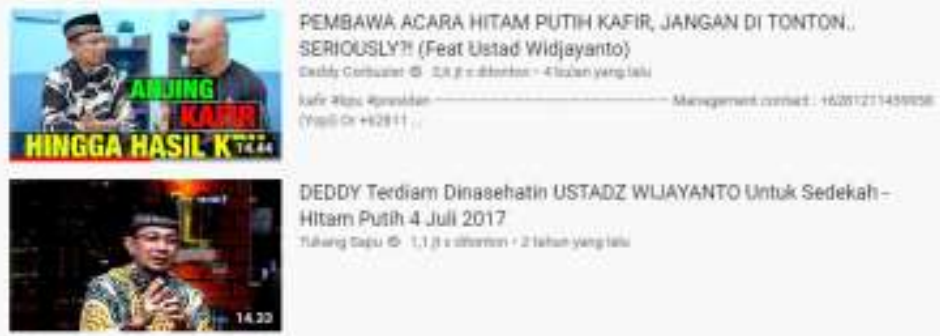

DEDOY Teediam Dinasehatin USTADZ WUAYANTO Untuk Sedekah-

Hitam Puth 4 jull 2017

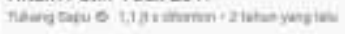

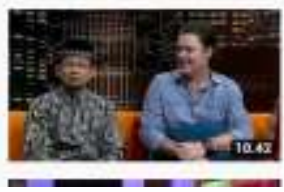

Tanya Ustadz Wijayanto Dergan The Scheunemann Family I HITAM PUTHH(10/01/19) Part 4

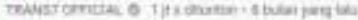

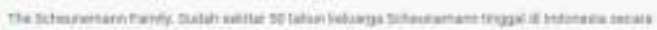

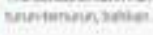

Sumber: www.youtube.com

Gambar 5. Video YouTube Deddy dan Ust. Wijayanto

Gerakan serupa juga dilakukan oleh Najwa Shihab. Presenter dan juga 
jurnalis ini memiliki 3,44 juta subscribers di channel YouTubenya. Selain membahas isu sosial dan politik, Najwa juga membuat program baru bertajuk "Shihab dan Shihab". Dalam program ini, Najwa Shihab mendiskusikan berbagai masalah agama, termasuk di dalamnya tentang toleransi, hubungan antar agama, dan lain sebagainya bersama ayahnya, Prof. Dr. Quraish Shihab. Prof. Quraish Shihab sendiri bukan tokoh baru di dunia pendidikan Islam di Indonesia. Ahli tafsir berusia 74 tahun sangat terkenal di Indonesia karena telah menerbitkan Tafsir al-Mishbah. Selain itu, masih ada sekitar 68 karya tulisnya dalam berbagai bidang agama Islam.

Merujuk pada video-videonya, Najwa membuat forum tanya jawab (question and answer) dengan Prof. Quraish tentang berbagai tema yang sesuai dengan berbagai usia. Tema yang diangkat seputar pernikahan, toleransi, keragaman, dakwah ala Nabi, politisasi agama, dan lain sebagainya. Obrolan yang ringan dan mencerahkan menjadi keunggulan dari program ini. Selain mereka berdua, Najwa juga sering mengundang tokoh-tokoh untuk ikut berdiskusi bersama mereka seperti Tantri Kotak saat membahas musik, Romo Budi saat membahas hukum mengucapkan Selamat natal, dan Zaskia Adya Mecca saat membahas tentang pernikahan dan kehidupan berumah tangga.

Program Najwa Shihab ini cukup berhasil. Hal tersebut dapat terlihat dari jumlah penonton yang menyaksikan tayangan tersebut. Kisaran penonton adalah 100 - 700 ribu penonton. Hal ini merupakan jumlah yang cukup besar mengingat nama Prof. Quraish Shihab yang tidak setenar para ustadz muda dan gaul yang akrab di benak para milennial. Dengan demikian, diharapkan para remaja mulai mengenal beliau dan juga berbagai pesan-pesan positif sebagai representasi Islam yang rahmatan lil alamin dan bukan Islam yang dekat dengan kekerasan dan terorisme.

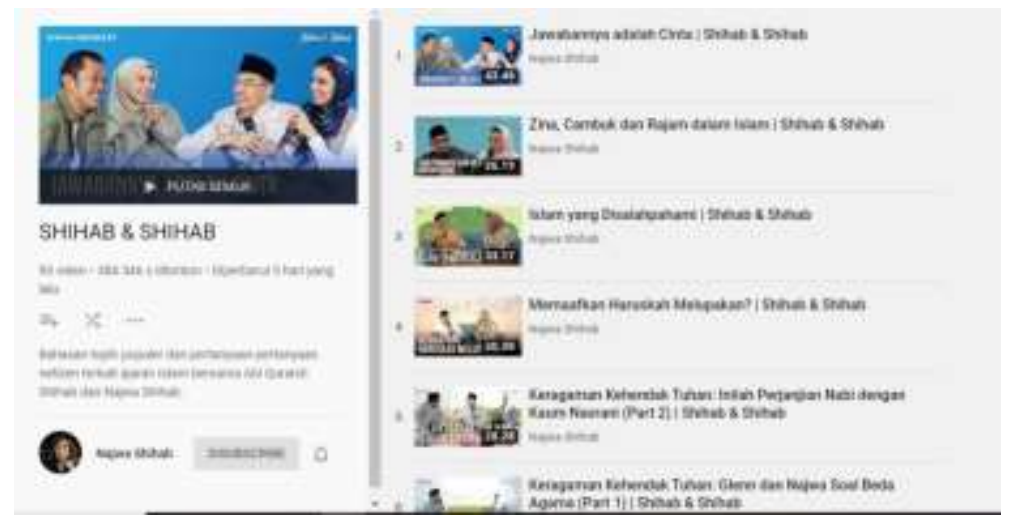

Sumber: www.youtube.com

Gambar 6 Playlist Video YouTube Shihab \& Shihab 
Dua fenomena di atas kembali memperkuat teori Dakwah yang tidak terbatas pada lisan dan aksi saja. Dakwah dengan media siirah chasanah, terutama dari para ulama dan pemuka agama yang memiliki pandangan agama yang tidak ekslusif merupakan salah satu media alternatif. Berbagai konten dengan narasinarasi radikalisme dan konservatisme dapat dibendung dengan membuat narasi tandingan di kanal YouTube. Bila tidak dapat membuat konten sendiri yang penuh dengan nilai-nilai Islam, berkolaborasi dengan para Content-creator kenamaan merupakan salah satu usaha dalam menarik minat para millennial. Sebagaimana diketahui, para millennial seringkali melihat berbagai tayangan dengan kemasan (media) yang digunakan. Bila tidak menarik secara visual, mereka tidak akan menonton tayangan tersebut meski memiliki banyak pesan positif.

Hal lain yang terpenting adalah menanamkan figur yang menjadi rolemodel positif bagi mereka. Seperti disebutkan di atas, para millennial seringkali gagal mencari role model yang baik bagi mereka. Mereka hanya memilih figure yang sering mereka lihat dan mereka saksikan di YouTube dan sebagainya. Di sisi lain, para pemuka agama dan tokoh yang memiliki cara berpikir multikulturalisme dan moderat lebih memilih dakwah offline dan tidak memiliki channel YouTube. Jikalaupun ada video mereka di YouTube, hanya sebatas rekaman ceramah dengan kualitas visual yang kurang menarik para millennial.

\section{Pengembangan Representasi Islam yang Positif}

Salah satu karakteristik remaja generasi millennial adalah tidak dapat berkonsentrasi dalam waktu lama. Menurut dr. Rizki Edmi Edison, Ph.D. dari UHAMKA (suara.com/10/9/2016), kemampuan remaja dan anak-anak saat ini untuk berkonsentrasi hanyalah pada 20 menit pertama. Hal tersebut banyak tidak dipahami oleh para pengajar sehingga tetap berfokus pada pemberian ceramah dengan waktu lama.

Mereka juga tidak suka dikekang dan selalu menginginkan hal-hal yang menyenangkan (fun). Dengan adanya bantuan sosial media seperti Instagram, Whatsapp, Facebook, dan YouTube, mereka justru banyak belajar secara otodidak dari berbagai sosial media tersebut. Survey membuktikan bahwa sekitar 86\% penduduk Indonesia usia produktif lebih banyak mengakses YouTube untuk mendapatkan informasi di samping mencari hiburan. Hal tersebut dapat dilihat dari data di bawah ini: 
Tabel.1

Persentase Penduduk Berumur 10 Tahun ke Atas yang mengakses Media Selama Seminggu Terakhir menurut Kelompok Umur dan Jenis Media 2015

\begin{tabular}{lllll}
\hline \multirow{2}{*}{$\begin{array}{l}\text { Kelompok Umur } \\
\text { Tahun) }\end{array}$} & Jenis Media & & \\
\cline { 2 - 5 } & Radio & Televisi & $\begin{array}{l}\text { Majalah/Surat } \\
\text { Kabar }\end{array}$ & $\begin{array}{l}\text { Artikel/Berita } \\
\text { Elektronik }\end{array}$ \\
$\mathbf{1 0 - 1 9}$ & 4,33 & 93,42 & 9,22 & 31,93 \\
$\mathbf{2 0 - 2 9}$ & 6,81 & 92,45 & 15,29 & 28,62 \\
$\mathbf{3 0 - 3 9}$ & 7,69 & 92,83 & 15,65 & 17,48 \\
$\mathbf{4 0 - 4 9}$ & 8,54 & 92,23 & 15,61 & 11,20 \\
$\mathbf{5 0 - 5 9}$ & 10,45 & 91,20 & 14,10 & 6,88 \\
$\mathbf{6 0 +}$ & 10,27 & 82,30 & 7,16 & 2,19 \\
\hline Jumlah & 7,54 & 91,47 & 13,11 & 18,89 \\
\hline
\end{tabular}

Sumber: BPS, Susenas MSBP 2015

Dari data di atas dapat dilihat bahwasanya menonton televisi menjadi favorit utama bagi penduduk Indonesia dalam memperoleh informasi. Hal tersebut sesuai dengan temuan Smithikrai (Smithikrai, 2016) yang menyatakan bahwa lebih mudah memberikan informasi dengan tayangan televisi, film, atau video karena menggunakan dua jalan dalam menyampaikan pesan, yaitu audio dan juga visual. Bahkan, perasaan dan emosi juga dapat dialirkan melalui video.

Posisi televisi di ruang keluarga juga mulai bergeser. Peran YouTube sedikit demi sedikit mulai akrab di ruang keluarga Indonesia. Mereka menggunakan YouTube untuk berbagai tujuan seperti mencari hiburan, mencari tutorial, mendengarkan lagu, mendengarkan ceramah, dan mencari berita.

Semakin besarnya peran YouTube bagi para remaja generasi milennial membuatnya memiliki posisi yang strategis. Bila dahulu channel televisi dan para pengisi acara di televisi banyak dikenal oleh masyarakat, namun saat ini tidak berlaku sama lagi. Para remaja dari generasi milennial lebih akrab dengan para influencer dan content-creator dari YouTube yang sering mereka saksikan.

Karenanya, tidak mengherankan bila content-creator seperti Ria Ricis dan Atta Halilintar yang memang memiliki pangsa penonton usia remaja (14-24 tahun) memiliki subscribers lebih dari 10 juta. Hal berbeda bila dibandingkan dengan content-creator yang memiliki pangsa usia produktif dan segmen tertentu (25-35 tahun) seperti Tim2One dan Cameo Project yang tidak mencapai 1 juta subscriber meski telah lebih dulu terjun ke YouTube. 
Para remaja milennial juga dalam posisi membutuhkan figur dalam keseharian mereka. Para content-creator dan influencer yang bertebaran di YouTube yang sering mereka lihat secara tidak langsung mempengaruhi pola pikir, sikap, dan tingkah laku mereka. Sedikit demi sedikit mereka menjadikan para influencer sebagai role model dalam kehidupan mereka.

Hal ini memang menjadi salah tantangan bagi dunia dakwah dan pendidikan Islam. Menyeru kepada kebaikan terasa sulit karena figur yang banyak mempengaruhi remaja adalah figur yang cenderung memiliki pola pikir khas remaja, bebas dan lepas. Mereka banyak mempertontonkan gaya bicara yang kasar, obrolan yang kurang sesuai dengan umur mereka, gaya hidup yang bertentangan dengan norma, dan banyak hal negatif lainnya. Katakanlah seperti Reza Oktovian, Awkarin, Anya Geraldine, Gofar Hilman, dan lain sebagainya. Gaya hidup mereka dipertontonkan kepada para penonton YouTube dan secara tidak langsung menjadi role model gaya hidup mereka mulai dari merokok, berkata kasar, minum bir, berpacaran, dan lain sebagainya.

Hal tersebut diperburuk dengan adanya gelombang ekspresi kesalehan digital (Annisa, 2018; Zahara, Wlidan, \& Komariah, 2020). Kesalehan digital adalah sebuah gerakan yang menyeru kepada kebaikan dan memperlihatkan berbagai perbuatan kebaikan di dunia maya. Hal baik ini seringkali disalahpahami oleh sebagian pengguna sosial media yang mempertontonkan kesalehan di dunia maya, namun melakukan hal yang bertolak belakang di dunia nyata. Karenanya, banyak remaja yang lebih memilih semboyan "Lebih baik aku buruk tapi apa adanya, daripada menjadi munafik seperti kalian".

Namun, tantangan ini tidak serta merta menutup jalan dakwah di dunia maya. Bila jeli, tantangan ini dapat dimanfaatkan sebagai sebuah peluang baru dalam berdakwah. Para remaja yang masih mencari jati diri ini merupakan sebuah floating mass yang dapat dibentuk dengan berbagai warna sesuai dengan apa yang mempengaruhinya.

Sebagaimana pesan-pesan buruk dapat menyebar dengan cepat di dunia maya, begitupula dengan pesan-pesan baik. Internet, termasuk di dalamnya adalah YouTube merupakan ruang hampa yang dapat diisi dengan berbagai nilai, baik atau buruk. Karenanya, perlu menyediakan counter-narasi bagi pesan-pesan buruk di dunia maya.

Sayangnya, seringkali konten-konten yang mengandung pesan baik dan nilai dakwah tidak memiliki media dan kemasan yang menarik para penonton (the medium is the message) (Mcluhan, 1994). Konten-konten tersebut seringkali hadir dalam bentuk yang kaku, monoton, dan statis sehingga para remaja - yang memang tidak dapat berkonsentrasi lama - tidak tertarik untuk sekedar melirik konten-konten tersebut, apalagi untuk menonton hingga akhir dan menyerap pesan dan nilai kebaikan dalam konten tersebut. 
Kekurangan ini dimanfaatkan oleh beberapa pihak kurang bertanggungjawab untuk memberikan jawaban atas keringnya literasi agama di dunia digital. Mereka membuat konten-konten sederhana dengan media yang menarik para remaja. Tak ayal, mereka pun mencari informasi dan pelajaran seputar ajaran agama melalui media tersebut. Meskipun tujuan mereka adalah untuk menyebarkan nilai-nilai baik, namun seringkali pesan yang disampaikan tidak utuh dan kurang moderat. Akibatnya, para remaja yang menonton dan minim pengalaman akan ajaran Islam akan berpotensi besar terpapar paham radikalisme, fundamentalisme, fanatisme, bahkan terorisme.

Hal ini menjadi pekerjaan rumah yang besar bagi para pendakwah Islam dalam menyebarkan pesan-pesan dan contoh dari Islam yang moderat dan rahmatan lil alamin. Berbagai konten dakwah yang diselewengkan secara tidak langsung dapat menunjukkan representasi Islam yang lekat dengan radikalisme bahkan terorisme. Sebagaimana sering ditunjukkan di tahun-tahun belakangan ini, cukup sulit bagi para Muslim (khususnya di saat mereka berada sebagai minoritas) untuk keluar dari stigma radikalisme dan terorisme. Hal ini merupakan sebuah bentuk kesuksesan pihak yang tidak bertanggungjawab tersebut dalam menyebarkan pesan-pesan negatif mereka. Pesan negatif ini tidak hanya berdampak buruk pada hubungan intra agama Islam saja, namun juga berdampak buruk pada hubungan antar Islam dan agama lain.

Fanatisme agama dan fenomena kebenaran tunggal juga makin bermunculan. Yahya (Yahya, 2019) dalam penelitiannya menjelang pemilihan presiden, fanatisme di Indonesia semakin meningkat dengan adanya peran sosial media, salah satunya adalah YouTube. Gelombang yang sedemikian rupa membuat banyak persepsi para pemeluk agama lain terhadap Islam memburuk. Citra Islam yang direpresentasikan cenderung tertutup, eksklusif, dan fanatik pada satu golongan dan menyalahkan golongan yang berbeda dengan mereka, meski sama-sama memeluk satu agama.

Algoritma unik yang ada di YouTube juga membuat para remaja terperangkap dalam tontonan yang sesuai dengan keinginan dan kesukaan mereka. Ruang perjumpaan dengan golongan-golongan lainnya semakin terbatas. Bila tidak dibarengi dengan konten-konten yang membawa narasi positif, maka para remaja ini hanya akan menjadi kaum-kaum radikalis dan fundamentalis di masa depan.

Oleh karena itu, beberapa pihak mencoba menggunakan salah satu strategi dalam berdakwah dan menyebarkan pesan-pesan positif dengan media YouTube. Karena media yang digunakan seringkali kurang menarik, maka perlu usaha ekstra dalam menyebarkannya dan menarik minat para remaja milennial untuk menontonnya. Setelah menonton, diharapkan berbagai pesan dan pengalaman baik dapat ditransfer kepada mereka di samping transfer audio dan 
visual.

Berk (Berk, 2009) mengatakan bahwa penggunaan media film dan video dalam pembelajaran memberikan dampak psikologis yang signifikan kepada siswa. Saat mereka menonton film, pesan suara dan gambar tersampaikan disertai dengan pemindahan perasaan dan emosi seperti sedih, marah, bahagia, dan lainnya. Karenanya, emosi para siswa akan yang terbawa ketika menonton film akan meninggalkan kesan mendalam pada mereka

Menonton film juga merupakan salah satu kegiatan menangkap pesan seperti membaca. Perbedaannya adalah bahwa membaca membutuhkan lebih banyak latihan dan fokus yang tinggi. Sedangkan untuk menonton, dibutuhkan sedikit usaha dan fokus dan tidak memerlukan banyak latihan. Oleh karena itu, seorang anak akan lebih dahulu menguasai cara menonton film sebelum belajar membaca kata-kata (Goodman, 2003).

Membaca melibatkan banyak kemampuan kognitif siswa tersebut. Dalam membaca, siswa dituntut untuk menjalani proses melihat, mengenali huruf, memperhatikan, memahami maknanya, menyerap dan memproses makna yang diperoleh, dan menyimpannya. Di kemudian hari, saat diperlukan, mereka juga diharuskan untuk menggunakan memori kembali atau menghafal (Ampuni, 1998). Dengan demikian, membaca menjadi salah satu kegiatan yang memiliki dampak signifikan dalam pengembangan pengetahuan siswa secara rasional dan empiris.

Meskipun menonton hanya melibatkan sedikit usaha dan tidak perlu banyak belajar dan berlatih, tidak berarti menonton tidak melibatkan keterampilan sebagaimana yang dihasilkan dari proses membaca. Menurut Berk (Berk, 2009), setidaknya ada 20 potensi yang dihasilkan ketika siswa belajar menggunakan media film seperti mudah mendapatkan perhatian siswa, secara tidak langsung menuntut siswa untuk fokus, memberi siswa kesempatan untuk menggunakan ulasan imajinasi mereka, meningkatkan daya ingat siswa, memfasilitasi pesan penyerapan disampaikan, dan menjadikan pembelajaran lebih menyenangkan dan tidak membosankan.

Hasil penelitian Husmiati (Husmiati, 2010) tentang kelebihan dan kekurangan menggunakan film sebagai media pengajaran sejarah menunjukkan bahwa minat sebagian besar siswa belajar menggunakan media film. Mereka berpendapat bahwa dengan menonton film itu, mereka dapat melarikan diri dari kebosanan belajar situasi yang monoton. Suasana kelas juga menjadi menarik dan bervariasi sehingga membantu siswa memperoleh pemahaman, menstimulasi imajinasi mereka, mengkonkretkan hal-hal yang abstrak, dan pada akhirnya, mampu memberikan hasil belajar yang lebih baik.

Menonton film berdasarkan pengalaman belajar, afektif dan kognitif secara bersamaan. Keterampilan afektif terkait dengan nilai-nilai dan rasa, sedangkan 
kognitif berhubungan dengan bagaimana otak bekerja atau mental (Haryadi \& Aripin, 2015). Beberapa penelitian telah menemukan bahwa mempelajari teori dan konsep abstrak yang akan lebih mudah untuk menggunakan media audio dan visual daripada menggunakan media teks (Smithikrai, 2016).

Kegiatan mengajar, meningkatkan kemampuan kognitif dalam belajar adalah salah satu faktor yang mendukung keberhasilan peserta didik. Kemampuan kognitif pada pembelajar mandiri dapat dirangsang melalui lima tahap: a) memilih kata-kata yang cocok dalam proses pembentukan memori verbal; b) memilih gambar yang sesuai dalam proses pembentukan memori visual; c) mengatur kata-kata yang cocok dalam proses verbal; d) mengatur gambar yang sesuai dalam model proses visual; e) integrasi antara representasi verbal dan visual sebagai bentuk unit pengetahuan (Mayer, 2009).

Berdasarkan perspektif psikologi kognitif, pengetahuan dibagi menjadi empat kategori. Keempat kategori tersebut adalah pengetahuan faktual, pengetahuan konseptual, pengetahuan prosedural, dan pengetahuan metakognitif. Pengetahuan pertama terkait erat dengan pengetahuan tentang terminologi, perincian, dan unsur-unsur spesifik seperti kosa kata, catatan musik, dan sumber daya alam. Pengetahuan konseptual terkait erat dengan proses klasifikasi, kategorisasi, pengetahuan umum dan spesifik dan pengetahuan yang relevan tentang teori, model, dan struktur (Anderson \& Krathwohl, 2001).

Pengetahuan ketiga adalah pengetahuan tentang cara melakukan sesuatu. Pengetahuan ini terkait erat dengan keterampilan pencampuran warna, teknik dalam menggunakan algoritma, penerapan hukum fisika, dan penggunaan teknik ilmiah. Pengetahuan keempat adalah ilmu kognitif komprehensif dan telah menjadi kesadaran dalam diri seseorang. Pengetahuan ini terkait erat dengan pengetahuan tentang pengetahuan strategis, tugas kognitif, dan pengetahuan tentang diri sendiri (self-knowledge)(Anderson \& Krathwohl, 2001).

Merujuk pada pengetahuan metakognitif, seseorang mampu mengidentifikasi masalah, menganalisisnya, dan kemudian memberikan solusi untuk masalah tersebut. Perbedaan masalah dan latar belakang masalah memerlukan penekanan dan solusi yang berbeda satu sama lain. Kecerdasan metakognitif akan muncul dalam hal-hal seperti itu. Oleh karena itu, tidak salah jika kecerdasan atau pengetahuan dianggap sebagai kombinasi pengetahuan tentang situasi, kondisi, dan pengetahuan budaya (Anderson \& Krathwohl, 2001). 


\section{PENUTUP}

Perkembangan media digital bagaikan pisau bermata dua. Di satu sisi ia dapat dimanfaatkan untuk menyebarkan nilai-nilai positif. Namun, di lain sisi, ia justru sangat berpotensi dalam menyebarkan pengaruh buruk, khususnya kepada para generasi millennial. Mereka yang sedang dalam proses pencarian jati diri membutuhkan figur untuk menjadi role model dalam kehidupan mereka.

Selama ini, berbagai dakwah Islam yang moderat dan rahmatan lil alamin terbatas pada gerakan offline atau hanya menggunakan cara tradisional. Padahal, generasi millennial memiliki kecenderungan untuk lebih dekat dengan dunia maya dibandingkan dengan dunia nyata. Hal ini menimbulkan narasi-narasi yang mereka dapatkan dan menjadi panutan adalah narasi liar. Khususnya dalam ranah pendidikan agama, narasi keagamaan yang mereka dapatkan justru berasal dari berbagai narasi yang lekat dengan konservatisme dan radikalisme. Kehadiran media online khususnya Youtube meningkatkan geliat dakwah Islam dalam merepresentasikan Islam yang positif.

Dua solusi yang ditawarkan adalah solusi yang paling mungkin dilakukan. Berbagai narasi tandingan yang disajikan dalam bentuk video di YouTube tidak dapat serta merta menjadi solusi mujarab. Perlu strategi dalam pembentukan kemasan, media, bahkan figur-figur yang dilibatkan. Gerakan hashtag Creator for Change misalnya, banyak melibatkan para content-creator dari generasi millennial yang mengerti selera para pemirsa millennial.

Begitupula dengan gerakan kolaborasi dengan content-creator ternama. Menjadi salah satu cara bagaimana mengembangkan Islam yang positif. Ini adalah salah satu upaya dalam memperkenalkan para figur dan pemuka agama yang moderat dan menyeru kepada toleransi, saling menghargai, dan saling berbuat baik. Bahkan, salah satu harapan ke depannya adalah bila para contentcreator dengan subsribers yang banyak, seperti Ria Ricis, Atta Halilintar dan sebagainya justru berkolaborasi dengan para tokoh-tokoh masyarakat dan agama dalam membahas isu-isu sosial keagamaan di Indonesia hari ini.

\section{DAFTAR PUSTAKA}

Al-Rodhan, N., \& Stoudmann, G. (2006). Definitions of globalization: A comprehensive overview and a proposed definition. Program on the Geopolitical Implications of Globalization and Transnational Security, 1-21. https://doi.org/10.1177/0268580900015002003

Ampuni, S. (1998). Proses Kognitif Dalam Pemahaman Bacaan. Buletin Psikologi Universitas Gadjah Mada. Fakultas Psikologi, 6(2), 16-26. https://doi.org/10.22146/bpsi.7395

Anderson, L. W., \& Krathwohl, D. R. (2001). A taxonomy for learning teaching and 
assessing: a revision of Bloom's taxonomy of educational objetives (L. W. Anderson \& D. R. Krathwohl, eds.). New York: Addison Wesley Longman.

Annisa, F. (2018). Hijrah Milenial: Antara Kesalehan dan Populism. Maarif Institute, 13(2), 38-54. Retrieved from https://scholar.google.co.id/ scholar?hl=id\&as_sdt $=0 \% 2 \mathrm{C} 5 \& \mathrm{q}=$ tren + berhijrah + di + kalanga ++ milenial \&btnG $=\# d=$ gs_qabs\&u=\%23p $\% 3$ DTtbLVM96luMJ

Berk, R. (2009). Multimedia teaching with video clips: TV, movies, YouTube, and $\mathrm{mtvU}$ in the college classroom. International Journal of Technology in Teaching \& Learning, 5(1). https://sicet.org/main/wp-content/uploads/ 2016/11/ijttl-09-01-1_Berk.pdf

Bunt, G. R. (2003). Islam in the Digital Age: E-Jihad, Online Fatwas, and Cyber Islamic Environments. In Islam in the Digital Age. https://doi.org/10.2307/ j.ctt18fs6ck.5

Goodman, S. (2003). Teaching Youth Media: A Critical Guide to Literacy, Video Production, and Social Change. New York: Teachers College Press.

Hajar, I. (2018). YouTube Sebagai Sarana Komunikasi Dakwah di Kota Makassar (Analisis Sosial Media). Jurnal Al-Khitabah, 5(2), 95-109. https://core.ac.uk/download/pdf/234750242.pdf

Haryadi, T., \& Aripin, A. (2015). Melatih Kecerdasan Kognitif, Afektif, dan Psikomotorik Anak Sekolah Dasar Melalui Perancangan Game Simulasi "Warungku." Andharupa: Jurnal Desain Komunikasi Visual \& Multimedia, 1(02), 122-133. https:/ / doi.org/10.33633/ andharupa.v1i02.963

Haryanto, A.T. (2020) Riset: Ada 175,2 Juta Pengguna Internet di Indonesia, diakses 21 Mei 2020. https://inet.detik.com/cyberlife/d-4907674/riset-ada-1752juta-pengguna-internet-di-indonesia.

Herman, H. (2018) Survei: Pengguna Internet Indonesia 143,26 Juta Jiwa. diakses tanggal 10 Mei 2020 dari https://www.beritasatu.com/yudodahono/archive/479305/survei-pengguna-internet-indonesia-14326-jutajiwa

Hidayatullah, A. F. (2016). Twitter Sebagai Media Dakwah. Teknoin, 22(1), 3843.

Huntington, S. P. (1993). The Clash of Civilizations. USA: Foreign Affairs.

Husmiati, R. (2010). Kelebihan Dan Kelemahan Media Film Sebagai Media Pembelajaran Sejarah. Jurnal Sejarah Lontar, 7(2), 61. https://doi.org/ 10.21009/lontar.072.06

Kim, Y. Y. (1988). Communication and cross-cultural adaptation: An integrative theory Intercommunication. In Multilingual Matters, Ltd (Vol. 12). https://doi.org/10.1016/0147-1767(88)90020-x

$\begin{array}{ccccc}\text { Mayer, R. E. (2009). Multimedia Learning } & \text { (Second). }\end{array}$ 
Mcluhan, M. (1994). Understanding Media: The Extensions of Man. The MIT Press. https://doi.org/10.1212/WNL.0b013e318205d55a

Omar, F. I., Hassan, N. A., \& Sallehuddin, I. S. (2015). Role of Social Media in Disseminating Dakwah. In Islamic perspectives relating to business, arts, culture and communication (pp. 43-55). https:/ / doi.org/10.1007/978-981-287-429-0

Rofiuddin (2016) Jihad Selfie dan Cara Baru Perekrutan Teroris. diakses 27 Mei 2020 dari https://nasional.tempo.co/read/790592/jihad-selfie-dan-cara-baruperekrutan-teroris.

Saefulloh, R. (2019) Populasi Pengguna Internet Aktif Indonesia Capai 78\%. diakses tanggal 27 Mei 2020 dari https://www.wartaekonomi.co.id/read216563/ populasi-pengguna-internet-aktif-indonesia-capai-79

Smithikrai, C. (2016). Effectiveness of Teaching with Movies to Promote Positive Characteristics and Behaviors. Procedia - Social and Behavioral Sciences, 217, 522-530. https://doi.org/10.1016/j.sbspro.2016.02.033

Ting-Toomey, S. (1999). Communicating across Cultures. In The Guilford Press. https://doi.org/10.3138/9781442625006-012

Utomo, W.P. (2019) Indonesia Millenials Report 2019. Jakarta: Riset Idntimes.

Yahya, Y. K. (2018a). Phenomenological Approach In Interfaith Communication: A Solution to Allegation of Religious Blasphemy in Indonesia. Al-Tahrir: Jurnal Pemikiran Islam, 18(2), 237-254. https://doi.org/10.21154/altahrir.v18i2.1378

Yahya, Y. K. (2018b). Toleransi Antar Agama Dan Antar Etnis Di Desa Mamahak Teboq Kalimantan Timur. Palita: Journal of Social-Religion Research, 3(2), 165-180. https://doi.org/10.24256/pal.v3i2.56

Yahya, Y. K. (2019). Posisi Muslim Dalam Menentukan Pilihan di Pilpres 2019. POLITEA Jurnal Pemikiran Politik Islam, 2(1), 55-70. https://doi.org/10.1192/bjp.112.483.211-a

Zahara, M. N., Wlidan, D., \& Komariah, S. (2020). Gerakan Hijrah : Pencarian Identitas Untuk Muslim Milenial di Era Digital. Indonesian Journal of Sociology, Education, and Development, 2(1), 58-70.

Zaidan, A. K. (2002). Ushul ad-Da'wah (Ninth). Beirut: Resalah Publishers. 